\title{
Eritema anular centrífugo como marcador cutáneo de comorbilidades
}

\author{
Erythema annulare centrifugum as a \\ cutaneous marker of comorbidities
}

\author{
Myrna del Carmen Rodríguez Acar, ${ }^{\star}$ Fermín Jurado-Santa Cruz, ${ }^{\ddagger}$ María Teresa Rosas-Morett ${ }^{\S}$
}

\section{RESUMEN}

El eritema anular centrífugo es una dermatosis inflamatoria crónica, poco frecuente, que forma parte de los eritemas figurados. Hasta el momento, su patogenia es aún desconocida; sin embargo, se considera una dermatosis reactiva a diversos antígenos. Las lesiones generalmente se ubican en el tronco y extremidades inferiores; están constituidas por eritema y fina escama blanquecina, que confluyen formando placas de aspecto urticariforme, que adquieren una disposición anular, expandiéndose hacia la periferia, dejando un centro sano delineado por escama. Su evolución es recurrente. En las últimas décadas se ha detectado una relación entre esta patología y la manifestación de diversas enfermedades sistémicas, por lo que los autores sugieren que esta dermatosis podría ser considerada un marcador cutáneo de comorbilidades. En este artículo se realiza una revisión acerca del tema.

Palabras clave: Eritema anular centrífugo, eritema figurado, reacción a antígenos.

\section{ABSTRACT}

Centrifugal erythema annulare is a rare, chronic inflammatory dermatosis that is part of the figurative erythema. So far, its pathogenesis is still unknown, however, it is considered a reactive dermatosis to various antigens. The lesions are generally located on the trunk and lower extremities, consisting of erythema and fine whitish scales, which converge to form urticarial-like plaques that acquire an annular arrangement, expanding towards the periphery, leaving a healthy center outlined by a characteristic "trailing scale" on the advancing edge. Its evolution is recurrent. In recent decades, a relationship between this pathology and the manifestation of various systemic diseases has been detected, for which the authors suggest that this dermatosis could be considered a cutaneous marker of comorbidities. In this article, a review of the subject is made.

Keywords: Centrifugal annular erythema, figurative erythema, antigen reaction.

\section{INTRODUCCIÓN}

Los eritemas figurados se manifiestan clínicamente como diversas erupciones que adquieren una disposición anular y/o policíclica; algunas de éstas son fijas, aunque la mayor parte de ellas son migratorias. Muchas de estas afecciones parecen relacionarse con hipersensibilidad a fármacos, neoplasias, infecciones, picaduras de artrópodos o por constituyentes propios

\footnotetext{
* Jefa de consulta externa.

₹ Autoridad responsable.

$\S$ Residente de segundo año de Dermatología.

Centro Dermatológico «Dr. Ladislao de la Pascua», SSCDMX. México.
}

del huésped. Las principales dermatosis que se manifiestan con eritemas figurados son: eritema anular centrífugo, eritema gyratum repens, eritema migrans, urticaria anular, penfigoide ampollar, eritema multiforme, infección por dermatofitos y/o tiña versicolor, psoriasis anular, lupus eritematoso anular, eritema marginado, eritema necrolítico migratorio, enfermedad granulomatosa crónica, eritema anular familiar y eritema anular del lactante.

El eritema anular centrífugo (EAC) fue descrito por primera vez en 1916 por Darier como placas anulares

Citar como: Rodríguez AMC, Jurado-Santa Cruz F, Rosas-Morett MT. Eritema anular centrífugo como marcador cutáneo de comorbilidades. Rev Cent Dermatol Pascua. 2021; 30 (1): 11-19. https://dx.doi.org/10.35366/100586 
con bordes eritematosos indurados, cuyos hallazgos histopatológicos mostraban epidermis normal, con infiltrado linfohistiocitario.

Posteriormente, Ackerman detectó la existencia de dos tipos a nivel histopatológico: el superficial (constituido por un infiltrado linfohistiocitario perivascular leve, ligera espongiosis con microvesículas y paraqueratosis focal) y el profundo, en el que se observa un infiltrado perivascular con células mononucleares, en particular linfocitos, con disposición «en manguito», ubicado en dermis media y profunda. Estos términos siguen siendo aceptados hasta la actualidad. ${ }^{1,2}$

Años después, Colcott Fox sugirió el término «eritema gyratum perstans» para describir a esta dermatosis.

Su etiología y patogenia exactas son aún desconocidas. La mayor parte de las hipótesis formuladas se han centrado en las interacciones entre las células inflamatorias, sus mediadores y la sustancia fundamental, lo cual ocurre cuando antígenos extraños atraviesan la piel. En una serie se evaluó a 24 pacientes y en ninguno de ellos se encontró evidencia clara de causalidad. Se han comunicado casos de EAC asociados con neoplasias malignas, en los que la erupción desapareció después del tratamiento del tumor, pero a menudo recurrió con la recidiva de éste. En los diferentes informes de casos, se ha sugerido que su manifestación se debe a

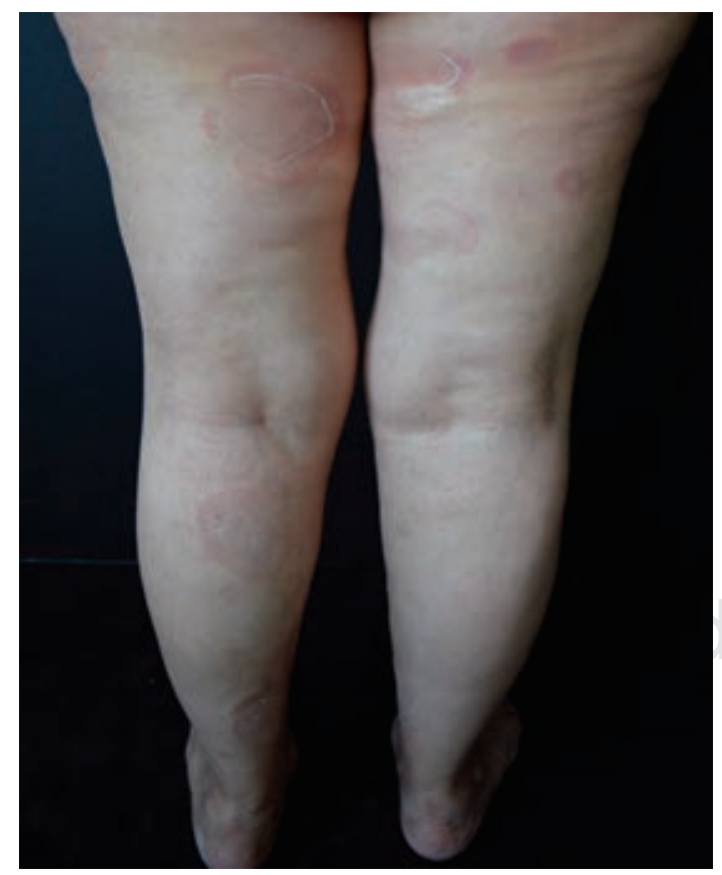

Figura 1: Lesiones en extremidades inferiores. Foto cortesía Dras. Karla Leticia Valdés Morales y Mireya Barragán Dessavre.

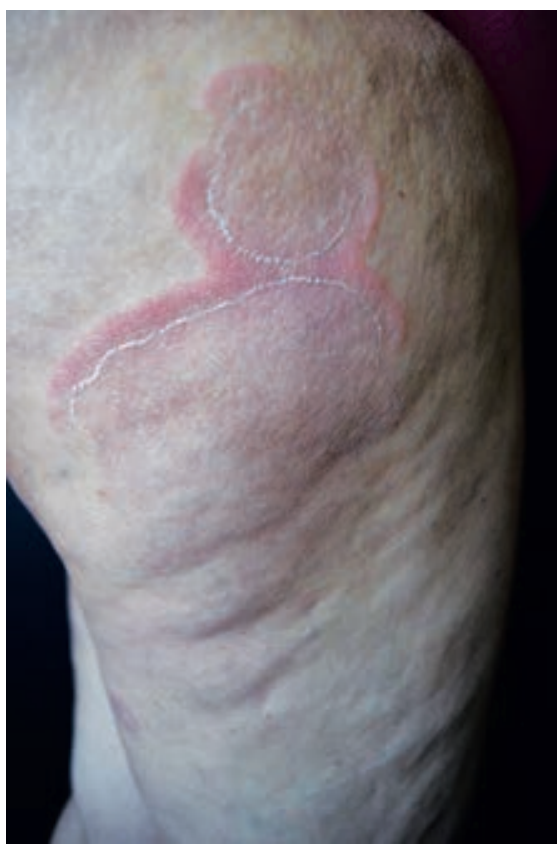

Figura 2:

Placas circulares, conformadas por eritema, lesiones de aspecto urticariformes $y$ escama que delinea el centro sano de la lesión.

Foto cortesía Dras. Karla Leticia Valdés Morales y Mireya Barragán Dessavre.

una reacción de hipersensibilidad a antígenos, que se desarrollan principalmente por infecciones micóticas, como los dermatofitos y la Candida; bacterianas, como la Pseudomona; víricas como el poxvirus; y parasitarias, entre otros; así como por la ingesta de algunos fármacos y alimentos; substancias inhaladas, enfermedades autoinmunes (como la enfermedad de Crohn), y las neoplasias (principalmente linfomas y leucemias). ${ }^{2}$ Debido a la diversidad de patologías asociadas al EAC, algunos autores lo han considerado como un patrón clínico reactivo, más que una entidad clínico-patológica. ${ }^{3}$

EI EAC puede aparecer a cualquier edad; sin embargo, presenta mayor incidencia en adultos jóvenes, y personas en edad media; no se han detectado diferencias en cuanto al género. ${ }^{4}$

Se caracteriza clínicamente por afectar en especial tronco, glúteos y extremidades inferiores (Figura 1). Rara vez compromete la cara. Inicia como una pequeña pápula eritematosa, en ocasiones de aspecto urticariforme, infiltrada, que va creciendo lentamente hacia la periferia hasta formar una figura en anillo, arciforme o policíclica; a medida que la zona central se aplana y remite, deja una piel sana o con leve escama blanquecina en el centro (Figura 2). Puede alcanzar un diámetro de hasta $8-10 \mathrm{~cm}$. Las lesiones pueden ser solitarias (Figura 3), a menudo múltiples. El borde puede ser plano o fácilmente palpable, liso o con una leve escama. Los pacientes cursan con un cuadro generalmente asintomático, aunque a veces refieren prurito, que no suele ser intenso. ${ }^{3}$ Luego 


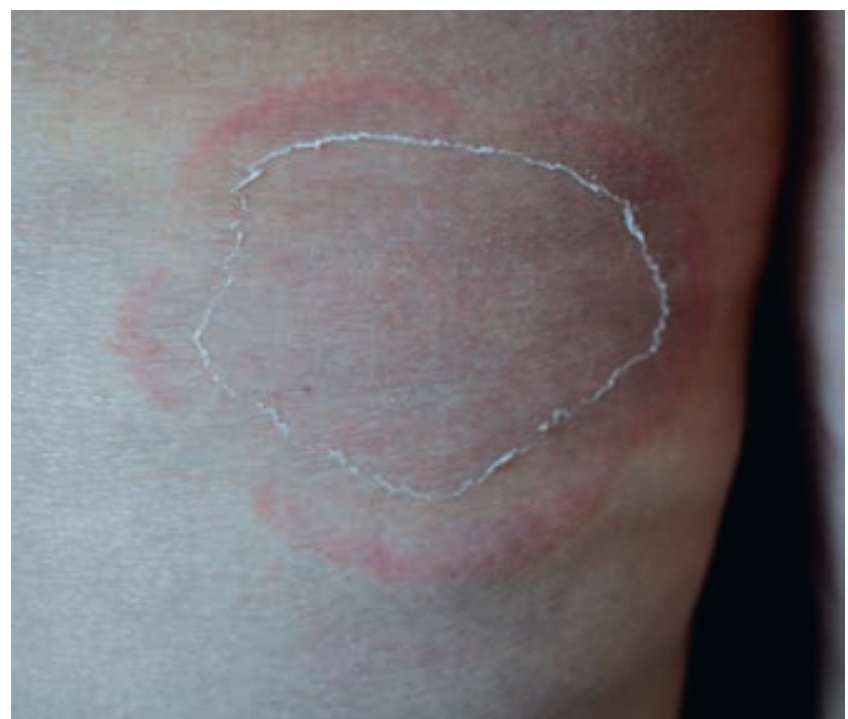

Figura 3: Placa circular con la típica escama en el borde interno. Foto cortesía Dras. Karla Leticia Valdés Morales y Mireya Barragán Dessavre.

de un lapso variable (por lo general meses), las lesiones desaparecen, a menudo para ser reemplazadas por otras nuevas, por lo que la dermatosis puede persistir con fluctuaciones periódicas por muchos años. Las lesiones que progresan hacia una necrosis epidérmica se asocian con carcinoma pancreático.

El diagnóstico se realiza por correlación clínico-histopatológica, aunque en ocasiones la sola presentación clínica orienta al diagnóstico. En cuanto a los hallazgos histopatológicos, éstos dependerán del subtipo histológico, superficial o profundo, por lo cual Bressler y Jones han sugerido que se elimine el término EAC, y en su lugar se utilicen los términos eritema anular profundo o eritema anular superficial, según el caso.

En la variedad superficial pueden observarse cambios epidérmicos de paraqueratosis con espongiosis, con infiltrado denso de linfocitos e histiocitos (y con menor frecuencia, de eosinófilos) alrededor del plexo vascular superficial (Figuras 4 y 5). El edema en la dermis papilar es mínimo. En la variante profunda, el infiltrado invade hasta el plexo vascular profundo. Tiene una disposición característica en «manguito" alrededor de vasos superficiales y profundos; las células pueden extenderse hacia las paredes de los vasos pequeños; sin embargo, nunca se observa extravasación de fibrina; es una pseudovasculitis. La epidermis es prácticamente normal, aunque se han descrito queratinocitos apoptóticos y, ocasionalmente, cambios vacuolares. ${ }^{3}$ Weyers y colaboradores estudiaron 73 casos con EAC, 50 de ellos con la variedad superficial, y 32 con la profunda. En aquellos superficiales, se observó en 100\% infiltrado superficial, $80 \%$ presentó espongiosis (que generalmente era focal), así como paraqueratosis en dos tercios de los pacientes. La histopatología de los 32 casos de EAC profundo demostró la presencia de infiltrado profundo, y mínima o ausente paraqueratosis; en $69 \%$ de los casos se apreciaron melanófagos. ${ }^{3}$

Rara vez los pacientes cursan con eosinofilia en los tejidos y en la sangre periférica. En algunas ocasiones, el EAC puede representar una manifestación temprana del síndrome hipereosinofílico.

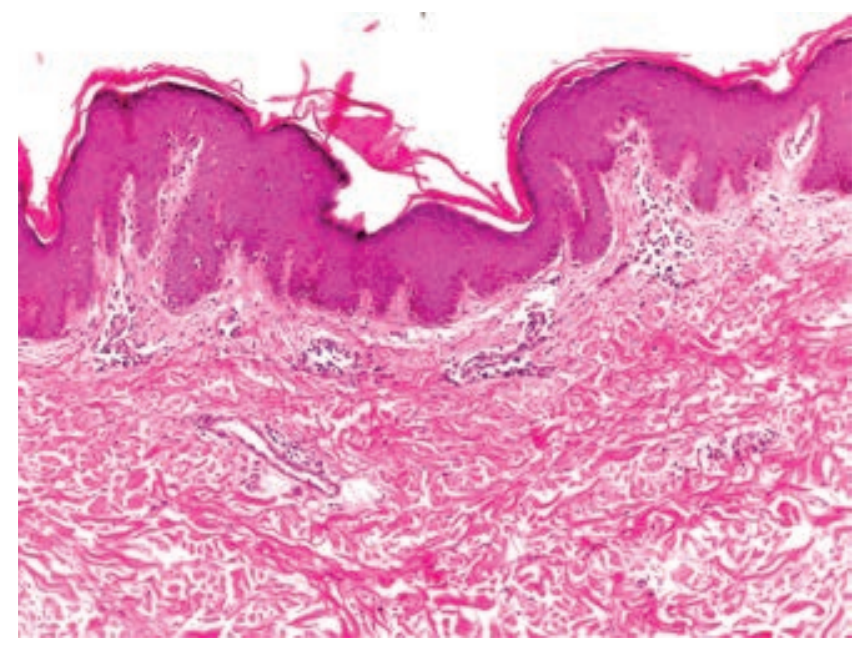

Figura 4: Epidermis plegada con escasa capa córnea, tapones córneos e hiperpigmentación de la capa basal. Dermis superficial con vasos dilatados (H\&E 10x).

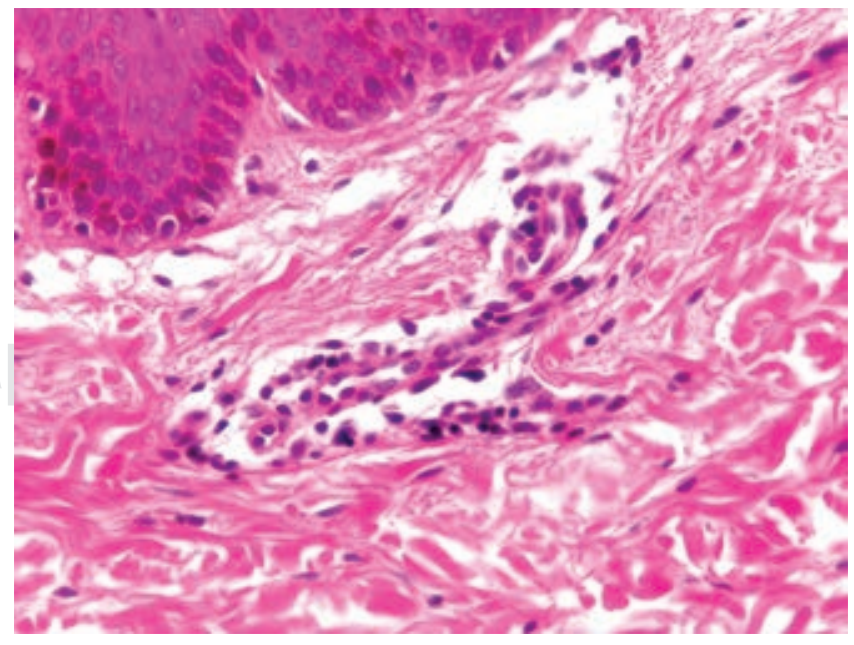

Figura 5: Infiltrados linfocitarios perivasculares (H\&E 40x). 
El manejo del eritema anular centrífugo se basa en buscar en forma minuciosa la causa subyacente y tratar de eliminarla. Se sugiere manejo con corticoesteroides tópicos y/o sistémicos, y con antihistamínicos en caso de prurito. En los últimos años, se han propuesto diferentes tratamientos: tacrolimus tópico, calcipotriol, antifúngicos por vía oral y antibióticos, e incluso se ha reportado el uso de etanercept; sin embargo, estos tratamientos se han administrado únicamente como paliativos, un tanto como ensayos terapéuticos. Hasta el momento, no existe estándar de oro para el tratamiento de esta patología..$^{4-7}$

\section{ERITEMA ANULAR FAMILIAR}

El eritema anular familiar fue descrito originalmente por Colcott Fox en 1881 como erythema gyratum repens. Desde entonces se han descrito pocos casos similares. Beare y colaboradores en 1966 en su artículo titulado Eritema anular familiar. Una mutación dominante aparentemente nueva, publicado en la revista British Journal Dermato/ realizaron una descripción detallada, acompañada de fotografías en color. La enfermedad parece heredarse en forma autosómica dominante y es extremadamente rara.

La erupción aparece en forma temprana, quizá sólo unos pocos días después del nacimiento. Las lesiones son similares a las del EAC habitual, pero más transitorias. Rara vez el paciente queda libre de ellas, persisten por muchos años. Se ha descrito un caso de EA en gemelos idénticos.

\section{ERITEMA ANULAR DE LA INFANCIA}

Este término fue descrito por primera vez por $\mathrm{Pe}$ terson y Jarratt en 1981, desde entonces, se han detectado numerosos casos. Como en el EAC convencional, la principal causa permanece sin identificarse. En este grupo etario, es importante excluir como causa desencadenante el lupus eritematoso, así como algunas otras infecciones cutáneas. Desde hace muchos años se sabe que las lesiones anulares en el lupus eritematoso neonatal se relacionan con la transmisión transplacentaria de anticuerpos maternos anti SSA (Ro).

Más recientemente se ha detectado que las lesiones anulares también se observan en pacientes con síndrome de Sjögren. De igual forma se observó positividad para anticuerpos SSB (La) en pacientes con lupus eritematoso túmido y EAC. Se ha descrito que estos pacientes cursan con EAC recurrente. Los pacientes más afectados son adultos jóvenes y niños, y el sexo femenino es el más afectado. Las personas originarias de Japón son más susceptibles a desarrollar este tipo de lesiones. Aunque el borde es más ancho, y la ubicación predominante es en áreas fotoexpuestas (cara), los casos clasificados previamente como EAC pueden ser explicados por este mecanismo.

Las imágenes clínicas e histopatológicas son similares a las observadas en los casos convencionales de EAC; sin embargo, algunos investigadores han detectado predominancia de eosinófilos en los cortes histopatológicos, así como eosinofilia periférica importante. También se ha reportado una variante neutrofílica.

En estos pacientes se documentó también una importante colonización intestinal por Candida albicans, así como infección por virus del Epstein-Barr, e infección por Pityrosporum.

Como tratamiento se sugiere la administración de interferón alfa y cromoglicato de sodio; sin embargo, desafortunadamente la evolución de estos pacientes no es adecuada, ya que la dermatosis persiste durante muchos años.

\section{MÉTODOS}

Para conseguir la información necesaria, se realizó una búsqueda en las siguientes bases de datos: PubMed, Ovid (EMBASE), OpenGrey database, EThOS e-theses online service y Cochrane Library and ClinicalTrials.gov hasta el 18 de abril del 2021. Con restricción a los artículos publicados en inglés, español o francés. Se utilizó el formato de búsqueda erythema annulare centrifugum. Se identificaron un total de 615 artículos. Se eliminaron los duplicados, y aquéllos sin asociación con alguna comorbilidad, quedando un total de 62 artículos. De éstos, 57 corresponden a reportes de casos (Tabla 1), cuatro a series de casos y sólo hubo una revisión.

\section{DISCUSIÓN}

En cuanto a la posibilidad de su manifestación como marcador cutáneo de comorbilidades, existen varios reportes en la literatura en los que se observó que en la mayoría de los EAC sí se detectó un padecimiento asociado como probable desencadenante del cuadro, ya que éste desapareció después de dar tratamiento para la comorbilidad asociada. De acuerdo con la investigación realizada por Weyers y colaboradores, las principales enfermedades asociadas al EAC fueron: infección por herpes simple, infección por Giardia lamblia, artritis reumatoide, trombocitemia, carcinoma mamario, asma, 
Tabla 1: Publicaciones de EAC y su patogénesis a nivel internacional.

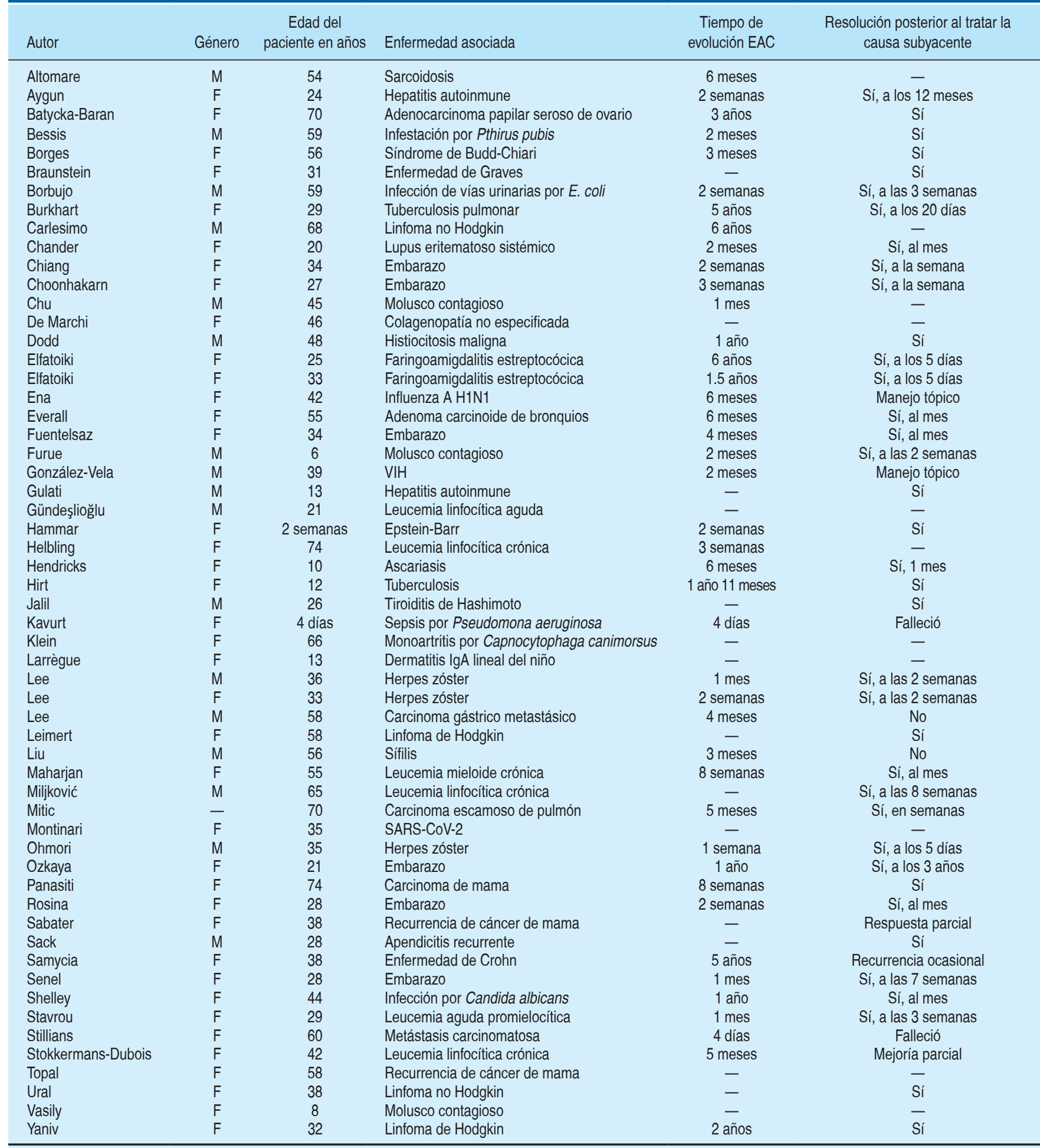

$\mathrm{EAC}=$ eritema anular centrífugo; $\mathrm{VIH}=$ virus de la inmunodeficiencia humana; $\mathrm{M}=$ masculino; $\mathrm{F}=$ femenino.

Elaborada por: Dra. María Teresa Rosas Morett. 
infecciones de tracto respiratorio superior, infecciones intestinales por Candida, reacciones a medicamentos y neoplasias subyacentes (carcinoma bronquial, carcinoma de colon, carcinoma de próstata y carcinoma metastásico de células claras). ${ }^{3}$

Por otro lado, Kim y colaboradores describieron una asociación entre EAC y distintas enfermedades en $72 \%$ de los pacientes, siendo las más comunes las infecciones micóticas, seguidas por dermatosis asociadas con eczema, mordeduras de insectos, psoriasis, dermatitis atópica, dermatitis seborreica y úlceras venosas; neoplasias, entre las que se encuentran cáncer de pulmón, cáncer colorrectal, linfoma no Hodgkin, leucemia mielocítica aguda, leucemia linfocítica aguda y carcinoma hepatocelular; otras enfermedades observadas fueron cirrosis, hemorragia subaracnoidea, diabetes mellitus, hipertensión y artritis reumatoide..$^{2,8}$

Mahood reportó 24 casos de EAC con asociación a enfermedades subyacentes. De acuerdo con su casuística, la resolución se alcanzó tratando la causa desencadenante en 18 de los 24 pacientes, la mayoría en un lapso menor a seis meses, reportando cuatro casos de importancia: dos asociados con enfermedad cerebrovascular, uno con ulceración duodenal y otro más con infección gingival activa. Varios pacientes refirieron cursar con patologías de larga evolución previas al debut de la dermatosis, como por ejemplo enfermedad de Paget, mielofibrosis, osteoartritis, enfermedad diverticular y glaucoma. ${ }^{9}$

Dentro de los reportes más frecuentes se encuentran los relacionados con neoplasias subyacentes, de los cuales $62.5 \%$ fueron de tipo linfoproliferativo, $37.5 \%$ de tipo sólido. En $46 \%$ de los pacientes, la aparición del EAC precedió al diagnóstico de la neoplasia subyacente, $33 \%$ se presentó de manera simultánea, y $21 \%$ de ellos se desarrolló después del diagnóstico de la misma. ${ }^{10}$ Cuando el EAC se manifiesta como una dermatosis paraneoplásica, se le denomina eritema anular centrífugo paraneoplásico (PEACE, por sus siglas en inglés), y la recurrencia del mismo puede ser indicativa de recaída de la neoplasia subyacente. ${ }^{11}$ Dentro de los reportes de casos en la literatura, encontramos dos con linfoma no Hodgkin, uno con linfoma de Hodgkin, uno con leucemia linfocítica aguda, uno con leucemia aguda promielocítica, tres casos de leucemia linfocítica crónica, uno con leucemia mieloide crónica, uno con histiocitosis maligna, uno con adenocarcinoma papilar seroso de ovario, dos con neoplasia pulmonar, uno con carcinoma de mama y cuatro con carcinoma recurrente o metastásico. .11-29 $^{-2}$

Otros padecimientos asociados son las infecciones. En la literatura consultada, encontramos un mayor nú- mero de casos relacionados con aquéllas de tipo viral, seguido por las enfermedades bacterianas, parasitarias y en último lugar las micóticas. En cuanto a las primeras, encontramos tres relacionadas con molusco contagioso, tres con herpes zóster, uno con influenza H1N1, uno seropositivo para $\mathrm{VIH}$, uno con Epstein-Barr y un último caso asociado con SARS-CoV-2. ${ }^{30-38}$ Los casos reportados asociados con infecciones bacterianas fueron dos con tuberculosis pulmonar, dos con faringoamigdalitis estreptocócica, uno con infección de vías urinarias por E. coli, un caso de sepsis por Pseudomona aeruginosa, uno con monoartritis por Capnocytophaga canimorsus y un paciente con sífilis. ${ }^{39-46}$ En cuanto a las parasitosis, únicamente se encontraron dos: uno por Pthirus pubis y otro por Ascaris. ${ }^{47,48}$ En nuestra búsqueda el único reporte de micosis asociada fue por Candida albicans. ${ }^{49}$

El embarazo también puede favorecer el desarrollo de un EAC, sin contar aún con una teoría que explique esta relación. Se detectaron varios reportes de casos en la literatura: mujer de 34 años con EAC, el cual inició a las 32 semanas de gestación (sdg) cuya dermatosis desapareció una semana posterior al parto; paciente de 27 años con EAC que debutó a las 36 sdg con borramiento de las lesiones cutáneas a los tres días postparto; mujer de 34 años con EAC debutante a las 28 sdg. Después de un mes postparto las lesiones desaparecieron completamente. Mujer de 28 años que debutó con EAC a las 26 sdg. ${ }^{50-54}$ Un caso con una evolución distinta fue el reportado por Ozkaya y colaboradores, en el cual la paciente de 21 años desarrolló un cuadro de EAC durante dos embarazos consecutivos, cursando con recaídas poco tiempo después de los partos. ${ }^{55}$

Otro grupo de enfermedades asociadas al EAC son las tipo autoinmune, con dos casos asociados a hepatitis autoinmune, dos con enfermedad tiroidea, uno con lupus eritematoso sistémico, otro con sarcoidosis, una dermatitis IgA lineal del niño, y una colagenopatía no especificada. ${ }^{56-62}$

Otras entidades reportadas con un caso en cada una de ellas fueron síndrome de Budd-Chiari, apendicitis recurrente y enfermedad de Crohn. ${ }^{63-66}$

Dentro de los reportes de casos, se observó que 17 pacientes pertenecían al sexo masculino (29\%), 39 al femenino (67\%), y uno no especificado. El promedio de edad de presentación fue de 38.7 años, con una moda de 58 años. El tiempo promedio en que los pacientes acudieron a valoración médica tras la aparición de la dermatosis fue de 11.8 meses. En 13 de los casos, el desenlace de la dermatosis no fue reportado, tres pacientes presentaron una remisión parcial o recurrencia, dos fallecieron, y 37 tuvieron remisión total del 
cuadro dermatológico tras haber recibido manejo para la comorbilidad subyacente, con un promedio de $11 \mathrm{se-}$ manas entre el manejo y la resolución de la dermatosis.

\section{CONCLUSIÓN}

EI EAC es una dermatosis poco frecuente que cursa con exacerbaciones y remisiones; por lo general resuelve después de tratar la probable causa subyacente o, en algunos casos, en forma espontánea. Con base en las observaciones realizadas por los diferentes autores, plasmadas en esta revisión, sí existe la relación ya señalada, aunque se requiere realizar más reportes de casos, y más investigaciones para sustentarlo, por lo cual es conveniente evaluar cada caso elaborando una historia clínica minuciosa, y solicitando los estudios pertinentes para descartar o corroborar las posibles causas desencadenantes de la dermatosis, ya que como se mencionó antes, el EAC puede ser considerado un marcador cutáneo para comorbilida-

Tabla 2: Causas de EAC por grupo etiológico.

Infecciosas

Tiña corporal

Eritema crónico migratorio

(eritema migrans)

Eritema marginatum

Dermatofitosis caracterizada con placas conformadas por eritema, escama, en ocasiones vesículas, que se disponen de forma circular con «borde activo» y piel sana al centro; pruriginosas. El diagnóstico diferencial puede establecerse con examen directo con $\mathrm{KOH}$ y cultivo Dermatosis asociada a enfermedad de Lyme (infección por Borrelia), asociada a fatiga, linfadenopatía y cefalea. Antecedente personal de visita a área endémica y picadura por garrapata. El diagnóstico diferencial es clínico por antecedentes de paciente

Dermatosis asociada a fiebre reumática; su presentación es rara, pero específica de esta enfermedad. Las lesiones aparecen de manera abrupta y desaparecen en el transcurso de horas a días; tienen distribución centrífuga, con predilección a tronco. El diagnóstico diferencial es clínico por la presentación aguda y síntomas asociados de la fiebre reumática

Eritema multiforme Lesiones anulares, con aspecto «en diana» de presentación abrupta, con predilección a extremidades, de inicio abrupto. El diagnóstico diferencial puede ser clínico y es evidente tras el estudio histopatológico

Neoplásicos y paraneoplásicos

Eritema necrolítico migratorio

Asociado a glucagonoma; se caracteriza por placas eritematosas, de formas policíclicas y arqueadas, en ocasiones con vesículas, ampollas o erosiones en la región genital, glútea y/o anal principalmente (pueden presentarse en extremidades inferiores y pliegues también). Asociadas a síntomas sistémicos (pérdida de peso, diarrea, vómito)

Eritema gyratum repens Eritema en anillos, concéntricos (policíclicos y serpiginosos), con escama que delinea la lesión; su instauración es rápida y se asocia a prurito intenso (mayor que en EAC). Se considera una alteración paraneoplásica. La rápida progresión asociada a prurito importante, ayuda al diagnóstico diferencial

Micosis fungoide Puede presentarse con placas anulares conformadas por eritema y escama de lenta progresión. El estudio histopatológico hace el diagnóstico diferencial

Otros

Granuloma anular

Sarcoidosis

Lupus eritematoso cutáneo subagudo

Pitiriasis rosada

Psoriasis

$\mathrm{KOH}=$ hidróxido de potasio; EAC = eritema anular centrífugo.

Elaborada por: Dra. Karla Leticia Valdés Morales. 
des, principalmente para aquellas enfermedades de tipo neoplásico e infeccioso.

Dentro de los principales diagnósticos diferenciales que se deben tener en cuenta se encuentran: tiña de la piel lampiña, eritema crónico migratorio, eritema multiforme, eritema necrolítico migratorio, eritema gyratum repens, micosis fungoide, granuloma anular, sarcoidosis, lupus eritematoso cutáneo subagudo, pitiriasis rosada y psoriasis (Tabla 2).,5,6

Por otra parte, el pronóstico se relaciona con la enfermedad asociada al EAC, ya que la dermatosis suele remitir al tratar la causa subyacente; sin embargo, puede cursar con recurrencias. ${ }^{7-10}$

\section{COMENTARIO}

Aunque es poco frecuente, es importante que los médicos especialistas en dermatología reconozcan esta entidad, para así poder realizar el protocolo de estudio pertinente en cada caso, tratando de detectar intencionadamente alguna patología asociada y diagnosticar en forma temprana, e iniciar así un tratamiento oportuno, tanto de la causa subyacente, como de la dermatosis.

\section{REFERENCIAS}

1. Bressler GS, Jones RE. Erythema annulare centrifugum. J Am Acad Dermatol. 1981; 4: 597-602.

2. Kim DH, Lee JH, Lee JY, Park YM. Erythema annulare centrifugum: analysis of associated diseases and clinical outcomes according to histopathologic classification. Ann Dermatol. 2016; 28: 257-259.

3. Weyers W, Diaz-Cascajo C, Weyers I. Erythema annulare centrifugum: results of a clinicopathologic study of 73 patients. Am J Dermatopathol. 2003; 25: 451-462.

4. Minni J, Sarro R. A novel therapeutic approach to erythema annulare centrifugum. J Am Acad Dermatol. 2006; 54: S134-S135.

5. Rao NG, Pariser RJ. Annular erythema responding to tacrolimus ointment. J Drugs Dermatol. 2003; 2: 421-424.

6. Gniadecki R. Calcipotriol for erythema annulare centrifugum. $\mathrm{Br} \mathrm{J}$ Dermatol. 2002; 146: 317-319.

7. Chuang FC, Lin SH, Wu WM. Erythromycin as a safe and effective treatment option for erythema annulare centrifugum. Indian $J$ Dermatol. 2015; 60: 519.

8. Kim KJ, Chang SE, Choi JH, Sung KJ, Moon KC, Koh JK. Clinicopathologic analysis of 66 cases of erythema annulare centrifugum. J Dermatol. 2002; 29: 61-67.

9. Mahood JM. Erythema annulare centrifugum: a review of 24 cases with special reference to its association with underlying disease. Clin Exp Dermatol. 1983; 8: 383-387.

10. Chodkiewicz HM, Cohen PR. Paraneoplastic erythema annulare centrifugum eruption: PEACE. Am J Clin Dermatol. 2012; 13: 239-246.

11. Mitic T, Adzic-Vukicevic T, Stojsic J, Dobrosavljevic D. Paraneoplastic erythema annulare centrifugum eruption as a cutaneous marker of squamous cell carcinoma of the lung. J Eur Acad Dermatol Venereol. 2020; 34: e617-e620.

12. Yaniv R, Shpielberg O, Shpiro D, Feinstein A, Ben-Bassat I. Erythema annulare centrifugum as the presenting sign of Hodgkin's disease. Int J Dermatol. 1993; 32: 59-61.

13. Batycka-Baran A, Zychowska M, Baran W, Szepietowski JC, Maj J. Erythema annulare centrifugum associated with ovarian cancer. Acta Derm Venereol. 2015; 95: 1032-1033.

14. Carlesimo M, Fidanza L, Mari E, Pranteda G, Cacchi C, Veggia B et al. Erythema annulare centrifugum associated with mantle b-cell nonHodgkin's lymphoma. Acta Derm Venereol. 2009; 89: 319-320.

15. Dodd HJ, Kirby JD, Chambers TJ, Stansfeld AG. Erythema annulare centrifugum and malignant histiocytosis--report of a case. Clin Exp Dermatol. 1984; 9: 608-613.

16. Gündeşlioğlu AO, Ertaş NM, Celebioğlu S, Hücümenoglu S. Erythema annulare centrifugum: an unusual presentation for acute leukemia. Plast Reconstr Surg. 2004; 113: 798-799.

17. Everall JD, Dowd PM, Ardalan B. Unusual cutaneous associations of a malignant carcinoid tumour of the bronchus--erythema annulare centrifugum and white banding of the toe nails. Br J Dermatol. 1975; 93: 341-345.

18. Helbling I, Walewska R, Dyer MJ, Bamford M, Harman KE. Erythema annulare centrifugum associated with chronic lymphocytic leukaemia. Br J Dermatol. 2007; 157: 1044-1045.

19. Lee HJ, Chang SE, Lee MW, Choi JH, Moon KC, Koh JK. Metastatic gastric carcinoma presenting as an erythema annulare centrifugumlike lesion. J Dermatol. 2008; 35: 186-187.

20. Leimert JT, Corder MP, Skibba CA, Gingrich RD. Erythema annulare centrifugum and Hodgkin's disease: association with disease activity. Arch Intern Med. 1979; 139: 486-487.

21. Maharjan K, Adhikari S, Amatya A, Kayastha G, Basnyat B. Erythema annulare centrifugum in a patient with chronic myeloid leukaemia on ponatinib. J R Coll Physicians Edinb. 2020; 50: 54-55.

22. Sabater V, Ferrando F, Morera A, Palomar L. Cutaneous metastasis of inflammatory breast carcinoma mimicking an erythema annulare centrifugum: a sign of locally recurrent cancer. Clin Exp Dermatol. 2016; 41: 906-910.

23. Stillians A. Erythema annulare centrifugum; its relation to internal disease. AMA Arch Derm Syphilol. 1953; 67: 590-593.

24. Topal IO, Topal Y, Sargan A, Duman H, Gungor S, Goncu OE et al. Erythema annulare centrifugum as presenting sign of activation of breast cancer. An Bras Dermatol. 2015; 90: 925-927.

25. Miljković J, Bartenjev I. Hypereosinophilic dermatitis-like erythema annulare centrifugum in a patient with chronic lymphocytic leukaemia. J Eur Acad Dermatol Venereol. 2005; 19: 228-231.

26. Panasiti V, Devirgiliis V, Curzio M, Rossi M, Roberti V, Bottoni U et al. Erythema annulare centrifugum as the presenting sign of breast carcinoma. J Eur Acad Dermatol Venereol. 2009; 23: 318-320.

27. Stokkermans-Dubois J, Beylot-Barry M, Vergier B, Bouabdallah $\mathrm{K}$, Doutre MS. Erythema annulare centrifugum revealing chronic lymphocytic leukaemia. Br J Dermatol. 2007; 157: 1045-1047.

28. Ural AU, Ozcan A, Avcu F, Kaptan K, Taştan B, Beyan C et al. Erythema annulare centrifugum as the presenting sign of $C D 30$ positive anaplastic large cell lymphoma--association with disease activity. Haematologia (Budap). 2001; 31: 81-84. 
29. Stavrou C, Mackenzie S, Pocock R, Wilson AJ. PEACE in the midst of an emergency: a rash not to miss. BMJ Case Rep. 2020; 13: e234642.

30. Chu CH, Tuan PK, Yang SJ. Molluscum contagiosum-induced erythema annulare centrifugum. JAMA Dermatol. 2015; 151: 1385-1386.

31. Furue M, Akasu R, Ohtake N, Tamaki K. Erythema annulare centrifugum induced by molluscum contagiosum. Br J Dermatol. 1993; 129: 646-647.

32. Vasily DB, Bhatia SG. Erythema annulare centrifugum and molluscum contagiosum. Arch Dermatol. 1978; 114: 1853.

33. Lee HW, Lee DK, Rhee DY, Chang SE, Choi JH, Moon KC et al. Erythema annulare centrifugum following herpes zoster infection: Wolf's isotopic response? Br J Dermatol. 2005; 153: 1241-1243.

34. Ohmori S, Sugita K, Ikenouchi-Sugita A, Nakamura M. Erythema annulare centrifugum associated with herpes zoster. J UOEH. 2012; 34: $225-229$

35. Ena L, Mazzarello V, Ferrari M, Ena P. Recurrent erythema annulare centrifugum due to influenza type A. Case Rep Dermatol.2021;13:134-140.

36. González-Vela MC, González-López MA, Val-Bernal JF, Echevarría $\mathrm{S}$, Arce FP, Fernández-Llaca H. Erythema annulare centrifugum in a HIV-positive patient. Int J Dermatol. 2006; 45: 1423-1425.

37. Hammar H. Erythema annulare centrifugum coincident with Epstein-Barr virus infection in an infant. Acta Paediatr Scand. 1974; 63: 788-792.

38. Montinari M, Atzori L, Valdevit S, Rongioletti F. Erythema annulare centrifugum with anosmia and ageusia in a SARS-CoV-2 exposed patient successfully treated with doxycycline. Int J Dermatol. 2021; 60: 384-386.

39. Hirt P, Price A, Alwunais K, Schachner L. An interesting case of coincidental epidermolytic hyperkeratosis and erythema annulare centrifugum in the setting of latent tuberculosis in a 12-year-old female. Int J Dermatol. 2019; 58: 1337-1340.

40. Burkhart CG. Erythema annulare centrifugum. A case due to tuberculosis. Int J Dermatol. 1982; 21: 538-539.

41. Elfatoiki FZ, Chiheb S, Marnissi S, El Attar H, Benchikhi H. Recurrent post-tonsillitis erythema annulare centrifugum: two cases. Ann Dermatol Venereol. 2014; 141:219-220.

42. Kavurt S, Aydemir O, Celik U, Bas AY, Demirel N. Erythema annulare centrifugum as the presenting sign of Pseudomonas aeruginosa sepsis in a newborn. Eur J Pediatr. 2013; 172: 847-849.

43. Klein C, Mahé A, Goussot R, Spielmann L, Gravier S, De Briel D et al. Multiple erythema annulare centrifugum associated with knee monoarthritis revealing Capnocytophaga canimorsus infection. Ann Dermatol Venereol. 2020; 147: 373-376.

44. Liu X, Liu Z, Zhang S. Aquagenic acrokeratoderma: a case report and review of the literature. Int J Clin Exp Pathol. 2020; 13: 1426-1430.

45. Liu ZH, Chen JF. Unusual huge erythema annulare centrifugum presentation of second syphilis. QJM. 2014; 107: 231-232.

46. Borbujo J, de Miguel C, Lopez A, de Lucas R, Casado M. Erythema annulare centrifugum and Escherichia coli urinary infection. Lancet. 1996; 347: 897-898.

47. Bessis D, Chraibi H, Guillot B, Guilhou JJ. Erythema annulare centrifugum induced by generalized Phthirus pubis infestation. Br J Dermatol. 2003; 149: 1291.
48. Hendricks AA, Lu C, Elfenbein GJ, Hussain R. Erythema annulare centrifugum associated with ascariasis. Arch Dermatol. 1981; 117: 582-585.

49. Shelley WB. Erythema annulare centrifugum due to Candida albicans. Br J Dermatol. 1965; 77: 383-384.

50. Choonhakarn $\mathrm{C}$, Seramethakun P. Erythema annulare centrifugum associated with pregnancy. Acta Derm Venereol. 1998; 78: 237-238.

51. Fuentelsaz V, Corredera C, Ara M, Carapeto FJ. Pregnancy-related erythema annulare centrifugum. Actas Dermosifiliogr. 2011; 102:66-68.

52. Chiang $\mathrm{CH}$, Lai FJ. Pregnancy-associated erythema annulare centrifugum. J Formos Med Assoc. 2015; 114: 670-671.

53. Senel E, Gulec AT. Erythema annulare centrifugum in pregnancy. Indian J Dermatol. 2010; 55: 120-121.

54. Rosina P, D'Onghia FS, Barba A. Erythema annulare centrifugum and pregnancy. Int J Dermatol. 2002; 41: 516-517.

55. Ozkaya E, Atci T, Erbudak Dinc EE, Elinc Aslan MS. Erythema annulare centrifugum: remission during two pregnancies and exacerbation in between. J Dtsch Dermatol Ges. 2017; 15: 1136-1138.

56. Altomare GF, Capella GL, Frigerio E. Sarcoidosis presenting as erythema annulare centrifugum. Clin Exp Dermatol. 1995; 20:502-503.

57. Aygun C, Kocaman O, Gurbuz Y, Celebi A, Senturk O, Hulagu S. Erythema annulare centrifugum: a rare skin finding of autoimmune hepatitis. Gastroenterology Res. 2010; 3: 96-98.

58. Braunstein BL. Erythema annulare centrifugum and Graves' disease. Arch Dermatol. 1982; 118: 623.

59. Chander R, Yadav P, Singh A, Nangia A. Systemic lupus erythematosus presenting as erythema annulare centrifugum. Lupus. 2014;23:1197-1200.

60. Gulati S, Mathur P, Saini D, Mannan R, Kalra V. Erythema annulare centrifugum with autoimmune hepatitis. Indian J Pediatr.2004;71:541-542.

61. Jalil P, Masood S, Fatima S. Erythema annulare centrifugum: a rare skin manifestation of Hashimoto thyroiditis. Cureus. 2020; 12: e9906.

62. Larrègue M, Bressieux JM, Laidet B, Cavaroc Y, Gallet P, de Giacomoni $P$ et al. Erythema annulare centrifugum revealing linear $\lg A$ dermatitis of childhood. Ann Dermatol Venereol. 1986; 113: 1213-1222.

63. De Marchi S, Cecchin E, De Marchi SU. Erythema annulare centrifugum. Am J Med Sci. 2014; 347: 414.

64. Borges AS, Brasileiro A, Santos S, Saiote J. Erythema annulare centrifugum in a patient with Budd-Chiari syndrome. Actas Dermosifiliogr. 2018; 109: 755-757.

65. Sack DM, Carle G, Shama SK. Recurrent acute appendicitis with erythema annulare centrifugum. Arch Intern Med. 1984; 144: 2090-2092.

66. Samycia M, Salopek TG. Erythema annulare centrifugum in a patient with Crohn disease. J Cutan Med Surg. 2012; 16: 442-444.

Correspondencia:

Dra. Myrna del Carmen Rodríguez Acar

Dr. Vértiz Núm. 464, esq. Eje 3 Sur,

Col. Buenos Aires, 06780 ,

Alcaldía Cuauhtémoc, CDMX.

Tel: 55 5519-6351

E-mail: roamacar@yahoo.com.mx 